within the Hydrographic Department. With his usual foresight, he realized that Great Britain soriously lacked a centre for research in this subject, and in 1944 he opened discussions in the Admiralty which eventually blossomed, six years later, into the National Institute of Oceanography. After retirement from the Navy, he kept himself fully abreast of all developments and served on the National Oceanographic Council and Executive Committee of the Institute, where his counsels were highly rospected. He attonded his last committee meeting as recently as June of this year, after which his health began to fail.

For his services in command of surveying ships during the First World War he was awardod the O.B.E. in 1919. In 1936 ho was mado C.B., and was crouted K.B.E. in 1942.

But his proudest moment was when ho was elected to the fellowship of the Royal Society in 1943.

Edgell was, from its beginning, very closely connocted with tho activities of tho International Hydrographic Bureau and attended four of tho quinquennial conferences at Monaco, and in 1939 was olected chairman of the Assembly.

Edgoll was appointed by the Admiralty to the Board of the Port of London Authority in 1941, and held this post until his seventioth birthday and was nominated as the Authority's representative on the Kent River Board. Ho was selected to be the acting conservator of the Mersey on retirement as hydrographer until 1951 .

Always a keen cricketer, Edgell lived an active life. Many were his talos of hard work and full enjoyment in his asa-going days, when there was no easy substitute for marching through rough country to make a triangulation station or pulling a whaler for weoks on ond to sound out the shallow areas of a survey. He took a very personal interest in his officors and men and would always bo forthcoming in giving advice and encouragement. His knowledge of hydrography was unlimited, and he had a flair for imparting his skill, while his memory never failed him for even the most precise point of dotail.

He was the last of the old generation of surveyors who had been brought up on the tenets of Wharton and Field and the hard life that the early surveyors had endured.

E. G. Irving

\section{Prof. T. M. MacRobert}

Thomas Murray MacRobert died at his home in Glasgow on November 1 at the age of seventy-eight. He held the chair of mathomaties in the University of Glasgow from 1927 until 1954, and bofore that had been assistant and lecturer in the same Univorsity. He was educated at Irvine Royal Academy and the University of Glasgow, whero he graduated in 1905 with first-class honours in mathematics and natural philosophy. From 1906 until 1910 he was a Major Scholar at Trinity Collego, Cambridge, and was a Wrangler in the Mathematical Tripos.

Prof. MacRobert was the author of numerous papers on the theory of special functions, on which he was an export; he continued to be active in research until just before he died. Much of his work was concernod with the proporties of $L$-funetions; these functions, which were invonted by him, contain as special cases several of the well-known functions of mathematical physics, and make it possible to give a unified treatment of the subject. His books on Functions of a Complex Variable (Macmillan, 1917) and Spherical Harmonics (Methuen, 1927) wero widely used by students, and he also collaborated with other writers in books on Bessel functions and trigonometry. Ho was responsible for the second revised odition of T. J. I'A. Bromwich's Infinite Series (Macmillan, 1926). The value and popularity of these works are attested by the number of difforent oditions in which thoy have appeared.

He was a friend and helper, not only to generations of Glasgow students, but also to many mathematicians from India and the East, who will soroly miss the willing assistance he gave them in their work, without ever expecting any acknowledgment. He was one of the original founders of the Glasgow Mathematical Association, of which ho was twico president and latterly honorary president. The flourishing state of the Association and the establishment and reputation of its Proceedings aro very largoly due to him.

His interests outside mathematics included hillwalking and playing the organ, and he took a prominent part in the proparation of the Congregational Churches' Hymn Book. The affoction and respect in which he was held by friends, colleagues and former students was amply demonstrated when, after his retirement in 1954, they commissioned Mr. Norman Hepple to paint his portrait. This excellent likeness, which tho University of Glasgow is fortunate to possess, also conveys something of his character and personality. $\mathrm{He}$ will be remembered for his kindliness and unfailing courtesy, but above all for his absolute integrity.

R. A. RANKIN

\section{Prof. E. F. Nash}

Prof. Eric NasH, profossor of agricultural oconomics in the University of Wales, Aberystwyth, died on October 31, aged fifty-eight. He is survived by a widow, a daughter and a son.

Nash started his academic careor with a first in Greats at University College, Oxford, went on to Modern Greats, in which he also took a first, and at one time seemed set for a caroor in puro oconomics (in 1930 he published Machines and Purchasing Power, which was an essay in monetary theory). But with his appointmont to the Ministry of Agricul. ture in 1934 he turned his attention to agricultural economics, and most of his work was done in that subject either in that Ministry, the Ministry of Food, the Control Commission for Germany, or, since 1946, at Aberystwyth. At the time of his death he was among the two or three best-known agricultural economists in Great Britain. This was a reputation gained not through the volume of his published work (indeed, during his twelve years of Govornmont service he was scarcely able to publish anything) but through the uniformly high quality of his articles, speeches, teaching and contributions to discussions and dobates. $\mathrm{He}$ was much in demand as a spoakor and membor of committees (Government and other), and his services were borrowed for quito long periods by the authorities in Jamaica, who were concerned with the low state of agricultural development in that country. $H \Theta$ had much to do there with the work of the Institute for Economic and Social Studies.

Nash had no special interest at any timo in ogriculture as an applied scienco. It is true that as provineial agricultural oconomist for Wales he had to devote himself to some extont to the practical problems of Welsh farming, especially on the farm management side, and that as a member of the 